Manuscript Number: MPB-D-20-00905R2

Title: First report of the carnivorous sponge Lycopodina hypogea (Cladorhizidae) associated with marine debris, and its possible implications on deep-sea connectivity

Article Type: Baseline Paper

Keywords: marine litter; litter-fauna interaction; deep-sea; carnivorous sponges; protected species; connectivity

Corresponding Author: Mr. Andreu Santín Muriel,

Corresponding Author's Institution: Institute of Marine Sciences

First Author: Andreu Santín Muriel

Order of Authors: Andreu Santín Muriel; Jordi Grinyó Andreu, Ph. D.; Meri Bilan, Ph. D. student; Stefano Ambroso, Ph. D. student; Pere Puig Alenyà, $\mathrm{Ph}$. D.

Abstract: Nowadays, there are an increasing number of reports of deep-sea accumulation of marine debris, often associated with a wide array of pernicious effects on benthic fauna. Nevertheless, there is still a huge knowledge gap regarding the interaction of benthic organisms and marine debris. In this paper, we report for the first time the colonization of plastic debris by the protected sponges Lycopodina hypogea. The sponges were discovered growing on plastic debris tangled with nylon ropes on the Blanes canyon (northwestern Mediterranean Sea). Over 30 individuals of L. hypogea were identified attached on ca. $10 \mathrm{~cm} 2$ plastic debris, an unusual feature for a species mostly known for low-density populations and a patchy distribution. The implications of this discovery are discussed, and it is suggested that marine debris might provide substrate for benthic species on otherwise unsuitable habitats, with its possible role as stepping-stones for deep-sea benthic connectivity needing further study . 


\section{strapping band}

Lycopodina hypogea (Vacelet \& Boury-Esnault, 1996) 
It is here reported the usage of plastic debris by the sponge Lycopodina hypogea. More than 30 individuals were observed growing into polyethylene terephthalate bands.

This is an unusual report, as the species is characterized for low-densities and isolated records.

Marine debris could play an undisclosed role in deep-sea connectivity of sessile benthic fauna. 


\title{
First report of the carnivorous sponge Lycopodina hypogea \\ (Cladorhizidae) associated with marine debris, and its possible implications on deep-sea connectivity
}

\author{
Santín, A..$^{*}$, Grinyó, J. ${ }^{1}$, Bilan, M. ${ }^{2}$, Ambroso, S. ${ }^{1}$, \& Puig, P. ${ }^{1}$ \\ ${ }^{1}$ Institut de Ciències del Mar (ICM-CSIC), Barcelona, Spain. \\ ${ }^{2}$ Dipartamento di scienze e tecnologie biologiche e ambientali (DiSTeBA), University of Salento, \\ Campus Ecotekne, S.P.6. Monteroni, 73100, Lecce, Italy.
} *santin@icm.csic.es

\begin{abstract}
Nowadays, there are an increasing number of reports of deep-sea accumulation of marine debris, often associated with a wide array of pernicious effects on benthic fauna. Nevertheless, there is still a huge knowledge gap regarding the interaction of benthic organisms and marine debris. In this paper, we report for the first time the colonization of plastic debris by the protected sponges Lycopodina hypogea. The sponges were discovered growing on plastic debris tangled with nylon ropes on the Blanes canyon (northwestern Mediterranean Sea). Over 30 individuals of L. hypogea were identified attached on ca. $10 \mathrm{~cm}^{2}$ plastic debris, an unusual feature for a species mostly known for low-density populations and a patchy distribution. The implications of this discovery are discussed, and it is suggested that marine debris might provide substrate for benthic species on otherwise unsuitable habitats, with its possible role as stepping-stones for deep-sea benthic connectivity needing further study.
\end{abstract}

Keywords: marine litter; litter-fauna interaction; deep-sea; carnivorous sponges; protected species; connectivity.

Marine debris poses one of the main anthropogenic impacts with surging interest within both governmental and scientific communities (Ryan, 2015) due to its negative impacts on marine environments (e.g. Miyake et al., 2011; Ryan, 2015; Oliveira et al., 2015; Mecho et al., 2020). In this sense, while the real impact of marine litter is still difficult to quantify, it is, at best, underestimated (Ryan, 2015). Marine debris represents a major concern, not just for marine ecosystems, but for hundreds of marine species which are 
known to be directly or indirectly affected by it (Kühn et al., 2015). While the most visual example of such impacts might be that of the entanglement and/or consumption of marine litter by mammals, turtles and marine birds (Kühn et al., 2015), which ultimately leads to their death, marine litter generates a myriad of pernicious indirect effects on marine fauna (Sheavly \& Register, 2007). Beneath the sea surface, marine litter accumulates on the sea floor, even making its way down to bathyal and abyssal environments (Miyake et al., 2011; Cau et al., 2018), where the accumulation of debris can smother marine organisms and facilitate hypoxic conditions on its habitats (Gregory, 2009). This phenomenon is particularly prevalent in submarine canyons as, due to their geomorphology, they transport and act as deposits for marine litter (Schlining et al., 2013; Pham et al., 2014; Oliveira et al., 2015; Pierdomenico et al., 2019).

Additionally, marine litter is known to act as substrata for several sessile benthic taxa (Carter \& Gregory, 2005; Gregory, 2009) and, in the case of buoyant marine debris, it is known to act as vectors for the dispersal of organisms, including the spread of potential invasive species (Aliani \& Molcard, 2003; Gregory, 2009; Suaria, \& Aliani, 2014; Kiessling et al., 2015). This phenomenon has been widely reported in surface-floating debris, yet it is still seldom reported for deep-sea habitats (Carter \& Gregory, 2005), and mostly associated with large artificial structures (Glover \& Smith, 2003) and, to a lesser extent, derelict fishing gear (Battaglia et al., 2019).

In the present paper, we report, for the first time, evidence of colonization of marine debris by the protected sponge Lycopodina hypogea (Vacelet \& Boury-Esnault, 1996). This species is perhaps one of the most well-known sponges, as its first findings from a cave in Mediterranean French waters led to the discovery of the so-called "carnivorous sponges" (Vacelet \& BouryEsnault, 1995; 1996). As such, the species is considered emblematic of the Atlantic-Mediterranean waters (Chevaldonné et al., 2015), and it is protected under the Barcelona Convention (UNEP/MAP-SPA/RAC, 2018).

Samples were collected during the "ABRIC-1" cruise, from 13 to 29 February 2020, on board the R/V Sarmiento de Gamboa, using the ROV (Remotely Operated Vehicle) Liropus 2000. The main goal of this cruise was to explore 
and characterize deep-sea benthic habitats, between 600 to $1200 \mathrm{~m}$ depth, in

Order Poecilosclerida Topsent, 1928

Family Cladorhizidae Dendy, 1922

Lycopodina hypogea (Vacelet \& Boury-Esnault, 1996) morphology, targeting canyon wall areas that could host habitat-forming anthozoans such as frame-work building scleractinians, gorgonians and antipatharians. During the exploration of a Leiopathes glaberrima (Esper, 1788) assemblage in the eastern canyon flank ( $41^{\circ} 29,846^{\prime} \mathrm{N}$; $2^{\circ} 58,710^{\prime} \mathrm{E}$; Figure 1), at approximately $700 \mathrm{~m}$ depth, the ROV got entangled in a rope, which could have been part of derelict fishing gear. After performing several releasing maneuvers, the rope snapped and several meters remained attached to the ROV. On board, the rope was recovered and carefully examined, and was noted to be mostly composed of fragments of nylon rope and polyethylene terephthalate strapping band (PSB) (Figure 2). On a fragment of PSB of ca. $10 \mathrm{~cm}^{2}$ (10 cm length and $1 \mathrm{~cm}$ width) 31 stipitated sponges were observed attached to it, which were identified in situ as $L$. hypogea (see pointing arrow on Figure 2). While no other L. hypogea individuals could be observed on the initial onboard examination of the rope, the possibility of isolated individuals occurring on the parts of the PSB plastic band or the rope cannot be ruled out. After their detection, the PSB with the attached sponges was separated from the rest and placed inside an aquarium with closed circulation at $12^{\circ} \mathrm{C}$ and, posteriorly, transferred to the experimental aquarium zone at the Institut de Ciències del Mar (ICM-CSIC) in Barcelona (Figure 3). Additionally, the size of all individuals was recorded, and the demography of the PSB plastic debris' population was estimated by means of size-frequency distribution histograms and skewness and kurtosis tests as in Santín et al. (2019). Two of the sponge individuals were used for spicule preparations to certify the identification, following the standard procedures (Cristobo et al., 1993; all spicule measures are given as MIN. $\mathrm{MEAN} \pm \mathrm{SD}-\mathrm{MAX}$.) and are described below: 
Description: Small, white, stipitate sponge, with a basal attachment area, body (Figures $3 \& 4$ ). Most individuals did not show clear hunting filaments.

Skeleton. The stem is a dense, parallel-arranged, axis of styles, which progressively branches into tracts once inside the main body. Around these tracts there are also styles, arranged in a confused or unorganized pattern. Anisochelae are very abundant, located on the hunting filaments.

Spicules. Megascleres: styles to subtylostyles with a subtle tyle ('mycalostyles' like; Figure 5B) or fully-formed tylostyles, mostly straight or slight flexuous (Figure $5 \mathrm{~A}$ ). While there were no clearly distinguishable categories, the biggest ones were found in the stalk. Size $410-567.8 \pm 75-$ $930 \times 3-4.7 \pm 0.8-6 \mu \mathrm{m}$. Microscleres: characteristic palmate anisochelae (Figure 5C), small and strongly bent, with prominent alae on its biggest ends, and greatly reduced, teeth-like alae on the other. Size $11.5-13.7 \pm 2.1-16.5$ $\mu \mathrm{m}$. Forceps were not found.

A few decades ago, the chance encounter of an unknown cave sponge without a proper filtration system resulted in paradigm-changing phenomena, crystalizing in the discovery of carnivorous sponges (Vacelet \& Boury-Esnault, 1995). While sponges from the Cladorhizidae family had been known for centuries (Dendy, 1922), L. hypogea (mostly reported as Asbestopluma hypogea) was the first species where such a unique feeding habitus could be observed, becoming a model organism for the study of carnivorous sponges (e.g. Vacelet \& Duport, 2004; Martinand-Mari et al., 2012; Duport et al., 2014; Rastorgueff et al., 2015), and attracting the attention of both the scientific community and the general public towards this unique group, ultimately leading to its declaration as a protected species by the Barcelona Convention (UNEP/MAP-SPA/RAC, 2018).

While originally discovered in cave environments, the species was soon theorized to occur in deep-sea habitats (Vacelet, 1996) due to the shared similarities between both environments (Harmelin et al., 1997). Since then, several new sightings of the sponge have been reported in both littoral caves (Bakran-Petricioli et al., 2007) and deep-sea environments (Aguilar et al., 
2011; Calciani et al., 2013; Chevaldonné et al., 2015; Fourt, et al., 2017; Sitjá Nevertheless, and despite the intensive exploration of the deep-sea environments over the past decades, the species' sightings are still scarce, and it presents a rather patchy and disjunct distribution, where it very rarely occurs in great numbers (Chevaldonné et al., 2015).

While discovering the origin of organisms growing on artificial substrates might not be always possible (Goldstein et al., 2014), nearby known populations have been theorized as the most likely origin, as stated for deepsea corals growing onto abandoned, lost or otherwise discarded fishing gear in the deep-waters of the Strait of Sicily (Battaglia et al., 2019). In this regard, the presence of $L$. hypogea is known from recently discovered Cold Water Corals (CWC) at the Blanes canyon head (Santín et al., 2018), which might be the mostly likely source population for the PSB plastic debris population presented in this study. While a lot of attention has been paid to the role of drifting litter as a potential dispersal tool for non-native species (Gregory, 2009; Aliani \& Molcard, 2003; Suaria \& Aliani, 2014; Kiessling et al., 2015), little attention has been paid to its role in the connectivity of non-invasive species (Barnes \& Milner, 2005; Goldstein et al., 2014; Kiessling et al., 2015), especially in deep-sea environments (Carter \& Gregory, 2005). So far, oil platforms are the most iconic anthropogenic deep-sea structures providing substrate for benthic taxa (van Elden et al., 2019; Sommer et al., 2019; Birchenough \& Degraer, 2020), even in otherwise unfavorable environments (Friedlander et al., 2014), and acting as stepping stones for organisms' dispersal and connectivity between populations (Sammarco et al., 2012; Adams et al., 2014; van der Molen et al., 2018). In this sense, sponge larvae are generally seen as poor swimmers (Lanna \& Riesgo, 2019) with little dispersal capabilities (Uriz et al., 2008), even at a local scale (Uriz et al., 1998). While the PSB plastic debris upon which the sponges were attached was stationary at the time, entangled ropes and fishing lines are known to break periodically due to wearing, which might set free any buoyant pieces (Battaglia et al., 2019). Marine litter is known to be persistent in time and, if buoyant, it can be transported over great distances (Kiessling et al., 2015), 
ultimately acting as a major dispersal vector for both invasive and nonBarnes \& Milner, 2005; Gregory, 2009; Goldstein et al., 2014). Nevertheless, it is also worth noting that non-buoyant marine litter is also subjected to transport processes, especially in canyons (Schlining et al., 2013; Oliveira et al., 2015), where sedimentary transport processes and intense bottom currents carry marine litter across the deep-sea floor (Schlining et al., 2013; Pham et al., 2014; Oliveira et al., 2015; Pierdomenico et al., 2019). As such, while the potential effect of buoyant debris on benthic organisms' connectivity might be more visible, especially in shallow areas (Gregory, 2009; Kiessling et al., 2015), in deep-sea ecosystems, and particularly canyons, both buoyant and non-buoyant debris could have a similar potential undisclosed role in the connectivity and dispersion of deep-sea benthic organisms with patchy distributions, as is the case for L. hypogea.

In this regard, while mostly acknowledged as pernicious for benthic organisms (Golver \& Smith, 2003; Ryan, 2015), marine litter has also been observed to act as a substrate for benthic taxa (Pace et al., 2007; Gregory, 2009; Oliveira et al., 2015) with the potential to, paradoxically, increase biodiversity in impacted areas due to an increase in habitat heterogeneity (Katsanevakis et al., 2007; Pace et al., 2007). Moreover, some taxa larvae have been shown to preferentially settle on anthropogenic substrate rather than natural ones, which could translate into an enlargement of the distribution area for said species (Carter \& Gregory, 2005; Holst \& Jarms 2007). As such, the unexpected high density of $L$. hypogea (ca. 3.1 ind. $/ \mathrm{cm}^{2}$ ) reported here attached to PSB plastic debris could imply that marine litter might be a favorable substrate for their settlement and survival in certain conditions. Nevertheless, such a role would be highly dependent on the ability of a given taxa to sustain itself in an otherwise hostile, nutrient-less substrata (Kiessling et al., 2015). In this study, 31 individuals of $L$. hypogea could be observed attached to rather limited-size substratum (ca. $10 \mathrm{~cm}^{2}$ ). This is noteworthy, as the species usually has low densities, even in stable populations (ca. 0.04 ind./ $/ \mathrm{cm}^{2}$; Chevaldonné et al., 2015), with only one other report of a massive occurrence of $L$. hypogea at a small scale, with 71 individuals associated with 
coral rubble $\left(35 \mathrm{~cm}^{2}\right)$ in the Gulf of Cadiz (Sitjà et al., 2019). Additionally, the size-structure of the population was non-skewed and well-distributed, being dominated by medium-sized individuals (1-2 cm; Figure 6), which corresponds with well-established populations. Furthermore, both buds and 'juvenile' (ca. $0.5 \mathrm{~cm}$ ) sponges could be identified (Figure 4D), suggesting the population could be reproductive. As such, the high density of $L$. hypogea recorded here could respond to an initial stochastic colonization, with just a few or several larvae settling on the PSB plastic strand, with a posterior sexual or asexual reproduction, which would result in the observed sizestructure distribution. Nevertheless, the colonization of litter by benthic fauna seems to be subjected to a myriad of factors rather than random processes, ranging from the species' own biology to their behavior in relation to space and litter quality (Walker, 1994). Furthermore, as marine debris provide no nutrient source, the ability for food acquisition is one of the key elements in determining the successful colonization on marine debris (Kiessling et al., 2015). In this sense, the nylon rope, suspended approximately $20 \mathrm{~m}$ above the sea floor, might have provided carnivorous sponges with access to water masses exposed to stronger currents, similarly to the role provided by Cold Water Corals and other ecosystem engineers (Roberts et al., 2009). In this scenario, access to new food sources could have boosted L. hypogea's population settlement and growth on the PSB plastic debris. Interestingly, upon collection, all individuals presented roundish bodies (Figure 3 \& 4), which has been observed as a symptom of senescence and an indicator of starvation (Chevaldonné et al., 2015). The most likely explanations for this might be possible adverse environmental conditions surrounding the nylon rope at the time or stress upon recovery, yet no conclusions can be made. Nevertheless, after two weeks in aquaria the sponges reverted back to their normal shape, with clearly visible hunting filaments.

In conclusion, the indirect effects of marine debris on benthic communities is of major concern for marine conservation policies, yet we still have a poor understanding of these effects, especially in deep-sea environments. In this regard, marine debris is reported here as a viable habitat for deep-sea fauna, particularly for carnivorous sponges, indicating that these organisms might 
have a higher environmental plasticity than originally thought. Finally, it is theorized that derelict fishing gear and other anthropogenic debris might have, to a certain extent, a yet undisclosed role for deep-sea organisms' dispersion and connectivity, the magnitude of which is currently unknown.

\section{Acknowledgments}

The authors thank the crew of the R/V Sarmiento de Gamboa and the crew of the ROV Liropus 2000 for their help during oceanographic surveys. Finally, the authors would also like to thank Ruth Durán for helping create the study are map and Carlota R. Gazulla for her aid with general formatting. Additionally, the authors would like to specially thank Claudia Traboni for her drawings of the spicules and Rubén Duró from Science into Images (https://scienceintoimages.com/) for the photographical work. This work received funding from the Spanish Ministry of Science and Innovation (ABRIC Project, Ref. RTI2018-096434-B-I00).

\section{References}

Adams, T.P., Miller, R.G., Aleynik, D., Burrows, M. T., 2014. Offshore marine renewable energy devices as stepping stones across biogeographical boundaries. J. Appl. Ecol. 51 (2), 330-338.

Aguilar, R., López Correa, M., Calcinai, B., Pastor, X., De La Torriente, A., Garcia, S., 2011. First records of Asbestopluma hypogea Vacelet and BouryEsnault, 1996 (Porifera, Demospongiae Cladorhizidae) on seamounts and in bathyal settings of the Mediterranean Sea. Zootaxa. 2925, 33-40.

Aliani, S., Molcard, A., 2003. Hitch-hiking on floating marine debris: macrobenthic species in the Western Mediterranean Sea. In: Jones, M. B., Ingólfsson, A., Ólafsson, E., Helgason, G. V., Gunnarsson, K., Svavarsson, J. (Eds.) Migrations and Dispersal of Marine Organisms (Proceedings of the 37th European Marine Biology Symposium held in Reykjavík, Iceland, 5-9 August 2002). Springer, Dordrecht. pp. 59-67. 
Bakran-Petricioli, T., Vacelet, J., Zibrowius, H., Petricioli, D., Chevaldonné, P., Asbestopluma hypogea and Oopsacas minuta in the Mediterranean Sea. Mar. Ecol. 28 (Suppl. 1), 10-23.

Barnes, D.K.A., Milner, P., 2005. Drifting plastic and its consequences for sessile organism dispersal in the Atlantic Ocean. Mar. Biol. 146 (4), 815-825.

Battaglia, P., Consoli, P., Ammendolia, G., D'Alessandro, M., Bo, M., Vicchio, T.M., Pedà, C., Cavallaro, M., Andaloro, F., Romeo, T., 2019. Colonization of floats from submerged derelict fishing gears by four protected species of deep-sea corals and barnacles in the Strait of Messina (central Mediterranean Sea). Mar. Pollut. Bull. 148, 61-65.

Birchenough, S.N., Degraer, S., 2020. Science in support of ecologically sound decommissioning strategies for offshore man-made structures: taking stock of current knowledge and considering future challenges. ICES J. Mar. Sci. 77 (3), 1075-1078.

Carter, R., Gregory, M.R., 2005. Bryozoan encrusted plastic from the continental slope: eastern South Island, New Zealand. New Zeal. Nat. Sci. 30, 49-55.

Cau, A., Bellodi, A., Moccia, D., Mulas, A., Pesci, P., Cannas, R., Pusceddu, A., Follesa, M.C., 2018. Dumping to the abyss: single-use marine litter invading bathyal plains of the Sardinian margin (Tyrrhenian Sea). Mar. Pollut. Bull. 135, 845-851.

Chevaldonné, P., Pérez, T., Crouzet, J.M., Bay-Nouailhat, W., Bay-Nouailhat, A., Fourt, M., Almón, B., Pérez, J., Aguilar, R., Vacelet, J., 2015. Unexpected records of 'deep-sea' carnivorous sponges Asbestopluma hypogea in the shallow NE Atlantic shed light on new conservation issues. Mar. Ecol. 36 (3), 475-484.

Dendy, A., 1922. Report on the Sigmatotetraxonida collected by H.M.S. 'Sealark' in the Indian Ocean. In: Reports of the Percy Sladen Trust Expedition to the Indian Ocean in 1905, under the lidership of Mr. J. Stanley Gardiner, M. A. Vol. 7. Trans. Linn. Soc. Lond. 18 (1), 1-164. 
Dupont, S., Carre-Mlouka, A., Domart-Coulon, I., Vacelet, J., BourguetKondracki, M.L., 2014. Exploring cultivable Bacteria from the prokaryotic community associated with the carnivorous sponge Asbestopluma hypogea. FEMS Microbiol. Ecol. 88 (1), 160-174.

Fourt, M., Goujard, A., Pérez, T., Chevaldonné, P., 2017. Guide de la faune profonde de la mer Méditerranée. Explorations des roches et des canyons sous-marins des côtes françaises. Patrimoines naturels. Publications scientifiques du Museum national d'Histoire naturelle Paris. 75, 1-184. (in French).

Friedlander, A.M., Ballesteros, E., Fay, M., Sala, E., 2014. Marine communities on oil platforms in Gabon, West Africa: high biodiversity oases in a low biodiversity environment. PLoS One, 9(8): e103709.

Glover, A.G., Smith, C.R., 2003. The deep-sea floor ecosystem: current status and prospects of anthropogenic change by the year 2025. Environ. Conserv., 30 (3), 219-241.

Goldstein, M.C., Carson, H.S., Eriksen, M., 2014. Relationship of diversity and habitat area in North Pacific plastic-associated rafting communities. Mar. Biol. 161 (6), 1441-1453.

Gregory, M.R., 2009. Environmental implications of plastic debris in marine settings-entanglement, ingestion, smothering, hangers-on, hitch-hiking and alien invasions. Philos. T. R. Soc. B, 364, 2013-2025.

Harmelin, J.-G., Vacelet, J., 1997. Clues to deep-sea biodiversity in a nearshore cave. Vie Milieu, 47 (4), 351-354.

Holst, S., Jarms, G., 2007. Substrate choice and settlement preferences of planula larvae of five Scyphozoa (Cnidaria) from German Bight, North Sea. Mar. Biol. 151 (3), 863-871.

Katsanevakis, S., Verriopoulos, G., Nicolaidou, A., Thessalou-Legaki, M., 2007. Effect of marine litter on the benthic megafauna of coastal soft bottoms: a manipulative field experiment. Mar. Pollut. Bull. 54 (6), 771-778. 
Kiessling, T., Gutow, L., Thiel, M., 2015. Marine litter as habitat and dispersal vector. In: Bergmann, M., Klages, M., Gutow, L. (Eds.) Marine anthropogenic litter. Springer, Cham. pp. 141-181.

Kühn, S., Rebolledo, E.L.B., van Franeker, J.A., 2015. Deleterious effects of litter on marine life. In: Bergmann, M., Klages, M., Gutow, L. (Eds.) Marine anthropogenic litter. Springer, Cham. pp. 75-116.

Lanna, E., Riesgo, A., 2020. Sponge larvae do not swim that fast: a reply to Montgomery et al. (2019). J. Mar. Biol. Assoc. UK. 100 (1), 181-183.

Martinand-Mari, C., Vacelet, J., Nickel, M., Wörheide, G., Mangeat, P., Baghdiguian, S., 2012. Cell death and renewal during prey capture and digestion in the carnivorous sponge Asbestopluma hypogea (Porifera: Poecilosclerida). J. Exp. Biol. 215 (22), 3937-3943.

Mecho, A., Francescangeli, M., Ercilla, G., Fanelli, E., Estrada, F., Valencia, J., Sobrino, I., Danovaro, R., Company, J.B., Aguzzi, J., 2020. Deep-sea litter in the Gulf of Cadiz (Northeastern Atlantic, Spain). Mar. Pollut. Bull. 153, 110969.

Miyake, H., Shibata, H., Furushima, Y., 2011. Deep-sea litter study using deep-sea observation tools. In: Omori, K., Guo, X., Yoshie, N., Fujii, N., Handoh, I. C., Isobe, A., Tanabe S. (Eds.) Interdisciplinary Studies on Environmental Chemistry - Marine Environmental Modeling and Analysis. Terrapub. pp. 261-269.

Pace, R., Dimech, M., Camilleri, M., \& Schembri, P.J., 2007. Litter as a source of habitat islands on deepwater muddy bottoms. Rapp. Comm. int. Mer Medit. $38,567$.

Pierdomenico, M., Casalbore, D., Chiocci, F.L., 2019. Massive benthic litter funnelled to deep sea by flash-flood generated hyperpycnal flows. Sci. Rep. 9 (1), 1-10.

Pham, C.K., Ramirez-Llodra, E., Alt, C.H., Amaro, T., Bergmann, M., Canals, M., Company, J.B., Davies, J., Duineveld, G., Galgani, F., Howell, K. L., Huvenne, V.A.I., Isidro, E., Jones, D.O.B., Lastras, G., Morato, T., GomesPereira, J.N., Purser, A., Stewart, H., Tojeira, I., Tubau, X., van Rooij, D., 
Howell, K.L., 2014. Marine litter distribution and density in European seas, from the shelves to deep basins. PloS one, 9(4): e95839.

Oliveira, F., Monteiro, P., Bentes, L., Henriques, N.S., Aguilar, R., Gonçalves, J.M. (2015). Marine litter in the upper São Vicente submarine canyon (SW Portugal): Abundance, distribution, composition and fauna interactions. Mar. Pollut. Bull. 97 (1-2), 401-407.

Rastorgueff, P.A., Rocher, C., Selva, M., Chevaldonné, P., 2015. Preliminary DNA-based diet assessment of a gutless carnivore, the sponge Asbestopluma hypogea. J. Exp. Mar. Biol. Ecol. 467, 108-114.

Roberts J., Wheeler A.J., Freiwald A., Cairns S., 2009. Cold-Water Corals. The Biology and Geology of Deep-Sea Coral Habitats. Cambridge, UK: Cambridge University Press. 334 pp. ISBN - 978-0-521-88485-3.

Ryan, P.G., 2015. A brief history of marine litter research. In: Bergmann, M., Klages, M., Gutow, L. (Eds.) Marine anthropogenic litter. Springer, Cham. pp. $1-25$.

Sammarco, P.W., Brazeau, D.A., Sinclair, J., 2012. Genetic connectivity in scleractinian corals across the northern Gulf of Mexico: oil/gas platforms, and relationship to the Flower Garden Banks. PLoS One, 7(4): e30144.

Santín A., Uriz, M.J., Puig, P., 2018. Cryptic and rare sponges associated with Cold-Water Corals of the Blanes Canyon (northwestern Mediterranean Sea). 4th International Workshop on Taxonomy of Atlanto-Mediterranean Deep-Sea \& Cave Sponges, Marseille (France), 10th - 15th of September. Oral presentation.

Santín, A., Grinyó, J., Ambroso, S., Uriz, M.J., Dominguez-Carrió, C., Gili, J.M., 2019. Distribution patterns and demographic trends of demosponges at the Menorca Channel (Northwestern Mediterranean Sea). Prog. Oceanog. $173,9-25$.

Schlining, K., Von Thun, S., Kuhnz, L., Schlining, B., Lundsten, L., Stout, N. J., Chaney, L., Connor, J., 2013. Debris in the deep: Using a 22-year video annotation database to survey marine litter in Monterey Canyon, central California, USA. Deep Sea Res. Part I Oceanogr. Res. Pap. 79, 96-105. 
Sheavly, S. B., Register, K. M., 2007. Marine debris \& plastics: environmental concerns, sources, impacts and solutions. J. Polym. Environ. 15 (4), 301-305.

Sitjà, C., Maldonado, M., Farias, C., Rueda, J.L., 2019. Deep-water sponge fauna from the mud volcanoes of the Gulf of Cadiz (North Atlantic, Spain). J. Mar. Biol. Assoc. UK. 99 (4), 807-831.

Sommer, B., Fowler, A.M., Macreadie, P.I., Palandro, D.A., Aziz, A.C., Booth, D.J., 2019. Decommissioning of offshore oil and gas structuresEnvironmental opportunities and challenges. Sci. Total Environ. 658, 973981.

Suaria, G., Aliani, S., 2014. Floating debris in the Mediterranean Sea. Mar. Pollut. Bull. 86 (1-2), 494-504.

UNEP/MAP-SPA/RAC, 2018. SAP/RAC: SPA-BD Protocol - Annex II: List of endangered or threatened species, 1-9.

Uriz, M.J., Maldonado, M., Turon, X., Martí, R., 1998. How do reproductive output, larval behaviour, and recruitment contribute to adult spatial patterns in Mediterranean encrusting sponges?. Mar. Ecol. Prog. Ser. 167, 137-148.

Uriz, M.J., Turon, X., Mariani, S., 2008. Ultrastructure and dispersal potential of sponge larvae: tufted versus evenly ciliated parenchymellae. Mar. Ecol. 29 (2), 280-297.

Vacelet, J., 1996. Deep-sea sponges in a Mediterranean cave. In: Uiblein, F., Ott, J., Stachowitsch, M. (Eds.), Deep-sea and extreme shallow-water habitats: affinities and adaptations. Biosyst. Ecol. Ser. 11, 299-312.

Vacelet, J., Boury-Esnault, N., 1995. Carnivorous sponges. Nature, 373 (6512), 333-335.

Vacelet, J., Boury-Esnault, N., 1996. A new species of carnivorous sponge (Demospongiae: Cladorhizidae) from a Mediterranean cave. In: Willenz, Ph. (Ed.), Recent Advances in Sponge Biodiversity Inventory and Documentation. Bull. Inst. Roy. Sci. Nat. Belgique. Biol. 66, 109-115.

Vacelet, J., Duport, E., 2004. Prey capture and digestion in the carnivorous sponge Asbestopluma hypogea (Porifera: Demospongiae). Zoomorphology. 123 (4), 179-190. 
van der Molen, J., García-García, L. M., Whomersley, P., Callaway, A., Posen, P. E., \& Hyder, K. (2018). Connectivity of larval stages of sedentary marine communities between hard substrates and offshore structures in the North Sea. Sci. Rep. 8 (1), 1-14.

van Elden, S., Meeuwig, J., Hemmi, J.M., Hobbs, R., 2019. Offshore oil and gas platforms as novel ecosystems: A global perspective. Front. Mar. Sci. 6: 548.

Walker, I. 1994. The benthic litter-dwelling macrofauna of the Amazonian forest stream Tarumã-Mirim: patterns of colonization and their implications for community stability. Hydrobiologia. 291(2), 75-92.

Fig. 1 Map showing the location where the nylon and PSB plastic rope was encountered (Eastern Blanes canyon, north-western Mediterranean Sea). Projected view (UTM Zone 31N (WGS84)) with geographic (WGS84) coordinates indicated for reference.

Fig. 2 On board general picture of the nylon ropes captured by the ROV upon collection, with several black PSB plastic debirs (PSB) entangled to it. The white arrow points Lycopodina hypogea individuals $(L h)$ observed growing on the plastic debris. Additionally, individuals of Desmophyllum dianthus (Esper, 1794) $(D)$ can also be observed growing onto the nylon ropes. Picture by ABRIC-1 cruise team.

Fig. 3 A) General picture of the PSB plastic debris with the attached $L$. hypogea in the aquaria; the plastic was to be held to counter its buoyancy. B and C) Close up of the plastic debris; L. hypogea individuals of different sizes can be seen growing on both sides of the plastic, alongside bryozoans and hydroids D) Two individuals of $L$. hypogea fused at their heads. Pictures by Ruben Duró (ruben@scienceintoimages.com).

Fig. 4 A) Several L. hypogea individuals of different sizes, alongside bryozoans and hydroids. B) Close up of an L. hypogea individual (marked as Lh 1 in Fig. 2A). The body is fused in a single mass and hunting filaments 
cannot be distinguished. C) Two individuals of $L$. hypogea fused together, as previously reported in north Atlantic populations (Chevaldonneé et al., 2015). D) L. hypogea buds (B) with a button-like appearance and still completely attached to the substrate, and a juvenile (j), which has already developed a roundish body separated from the plastic by a short stalk. Pictures by Ruben Duró (ruben@scienceintoimages.com).

Fig. 5 Schematic representation of L. hypogea spicule set. A) Style B) Detail of the tyle of the subtylostyles; C) Anisochelae. Schemes were digitally produced by C. Traboni (traboni@icm.csic.es).

Fig. 6 Size-structure distribution for the L. hypogea individuals growing onto the PSB plastic debris. 


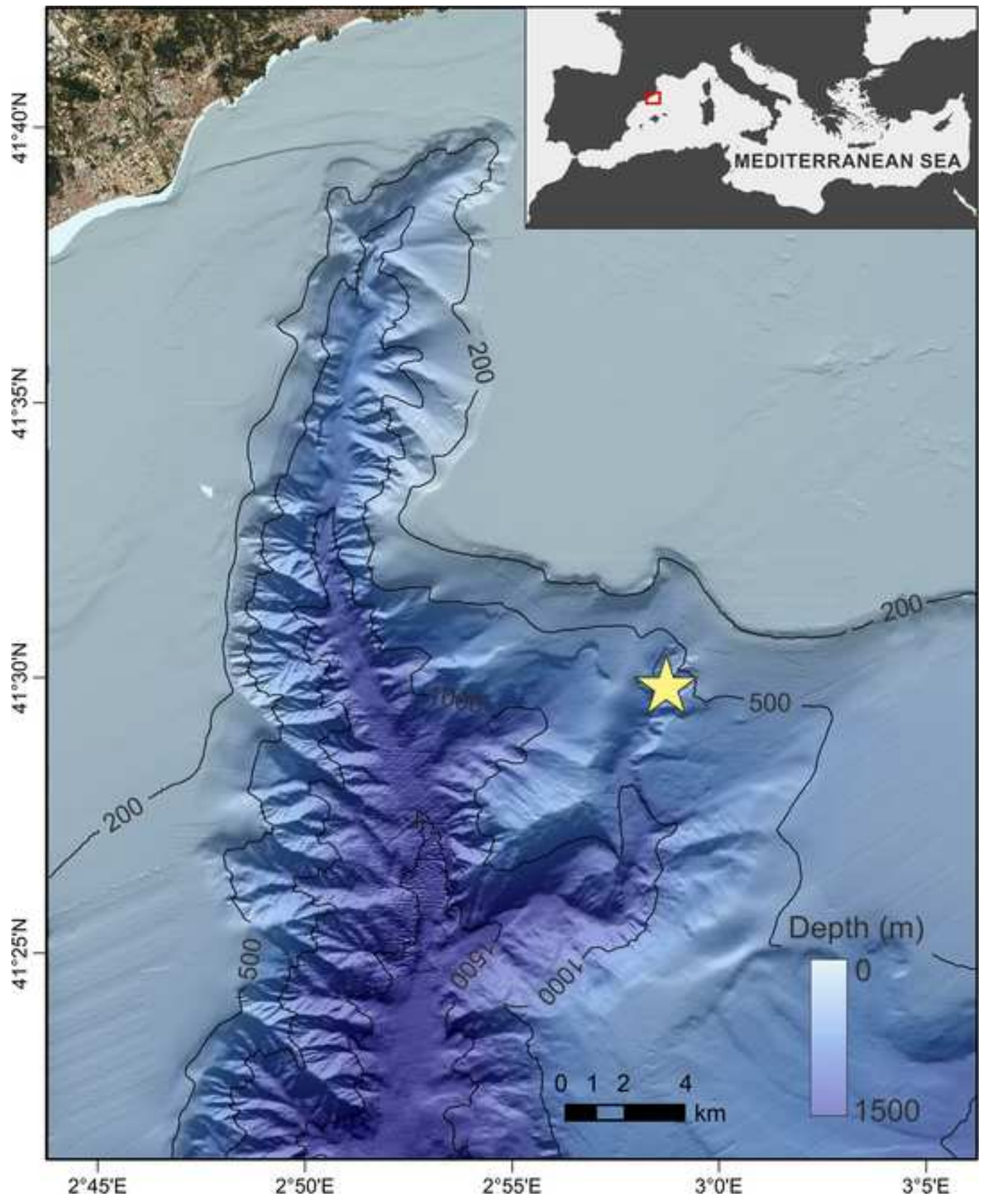


Figure 3

Click here to download high resolution image
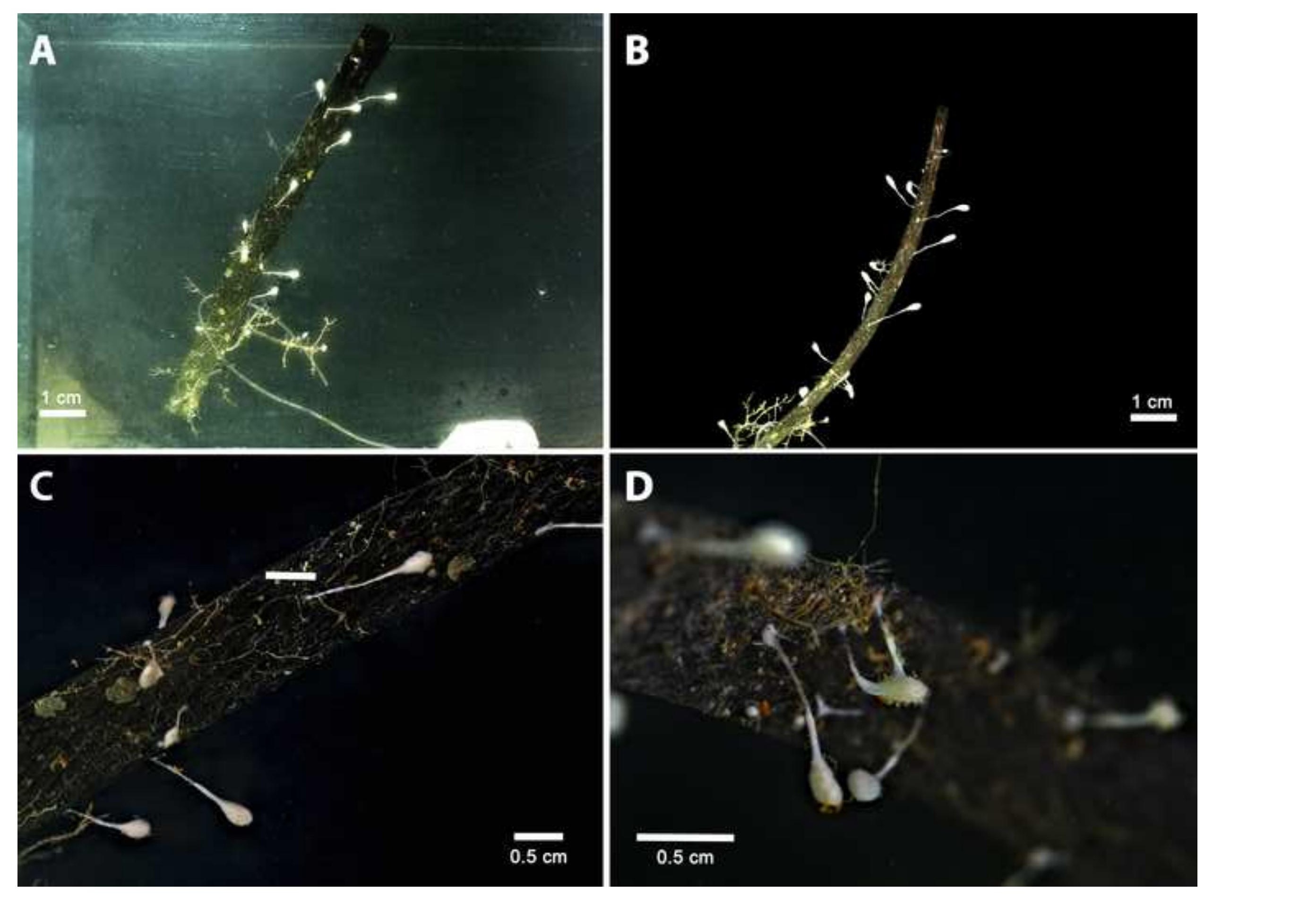
Figure 4
Click here to download high resolution image
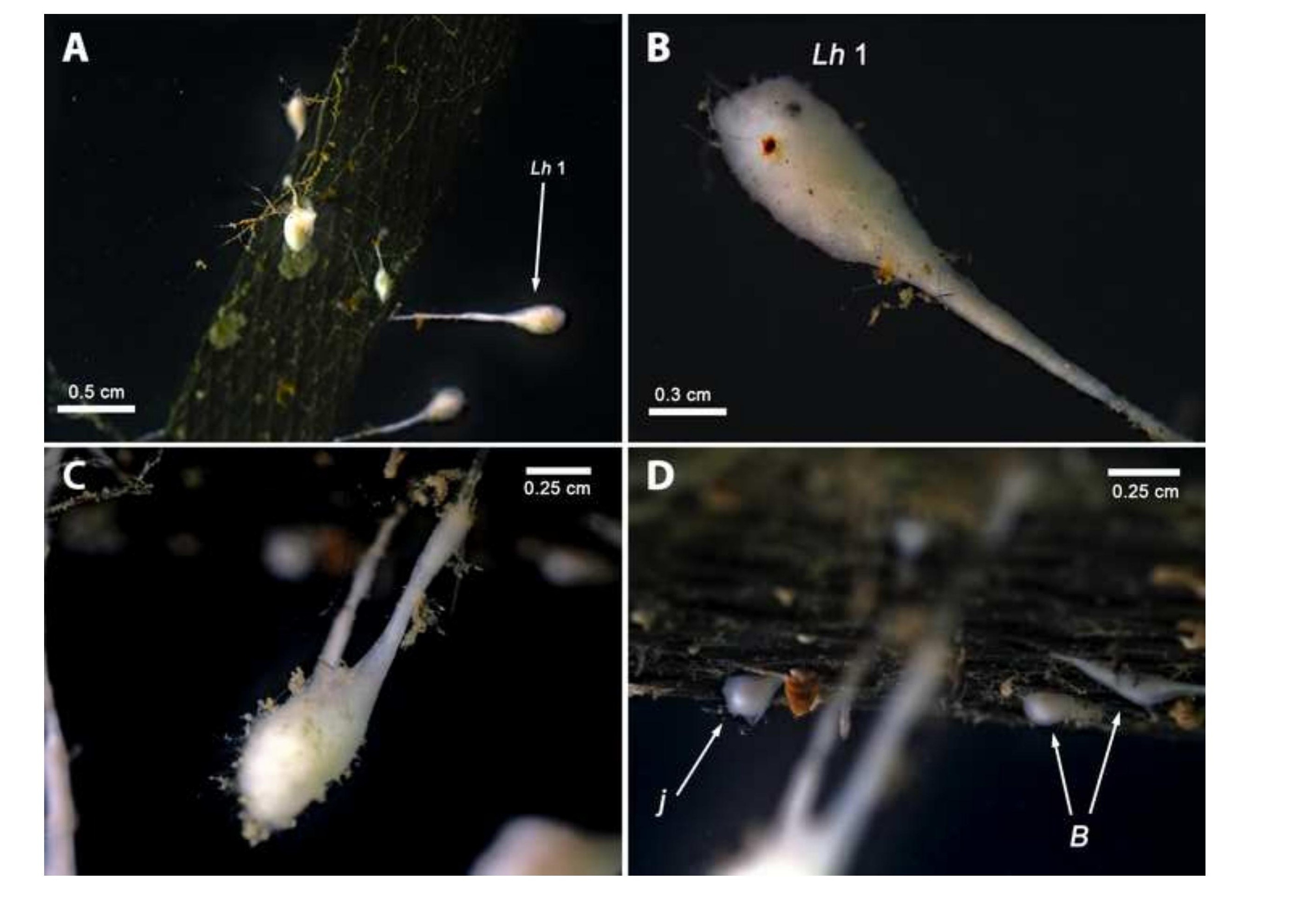
A.
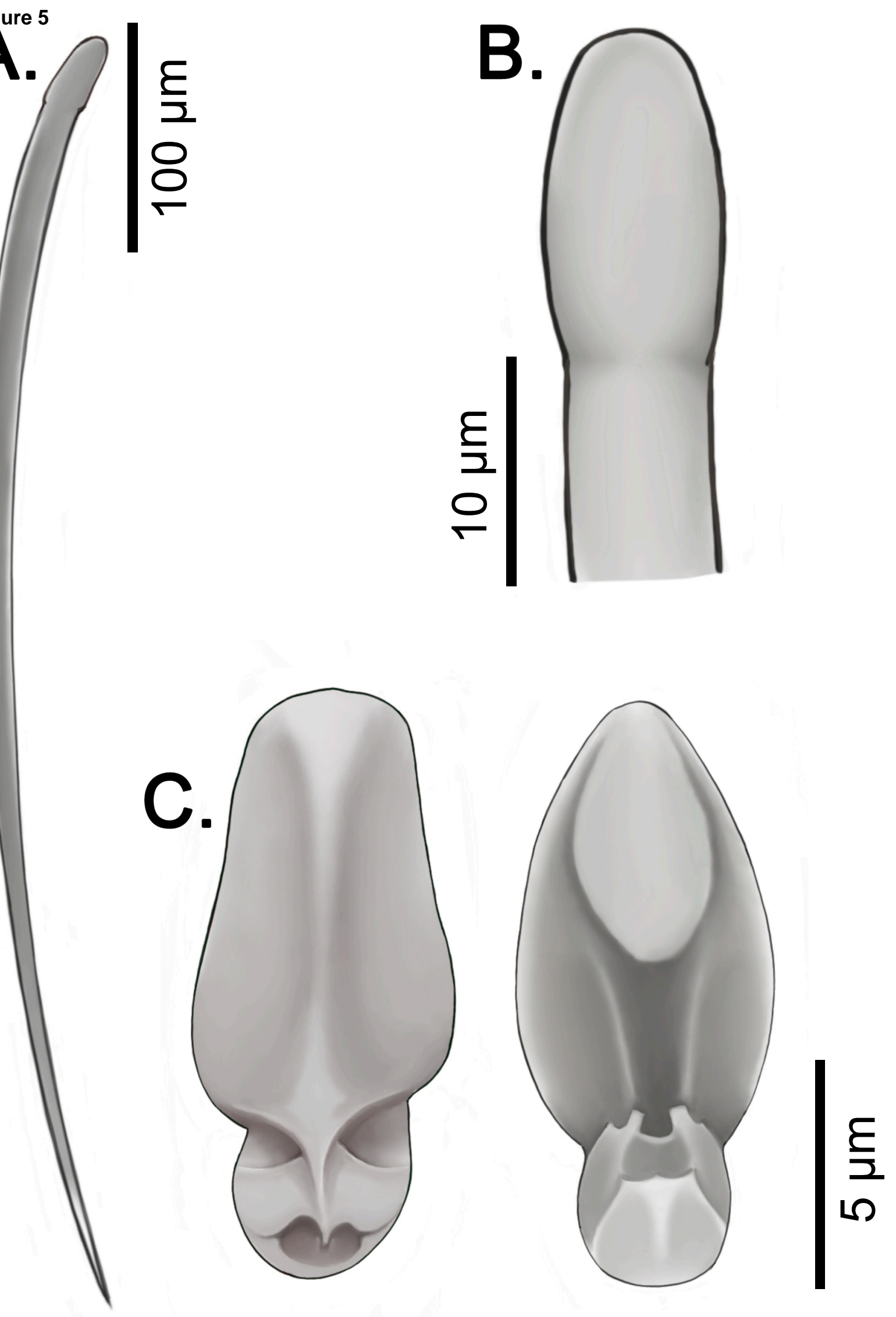

Figure 5
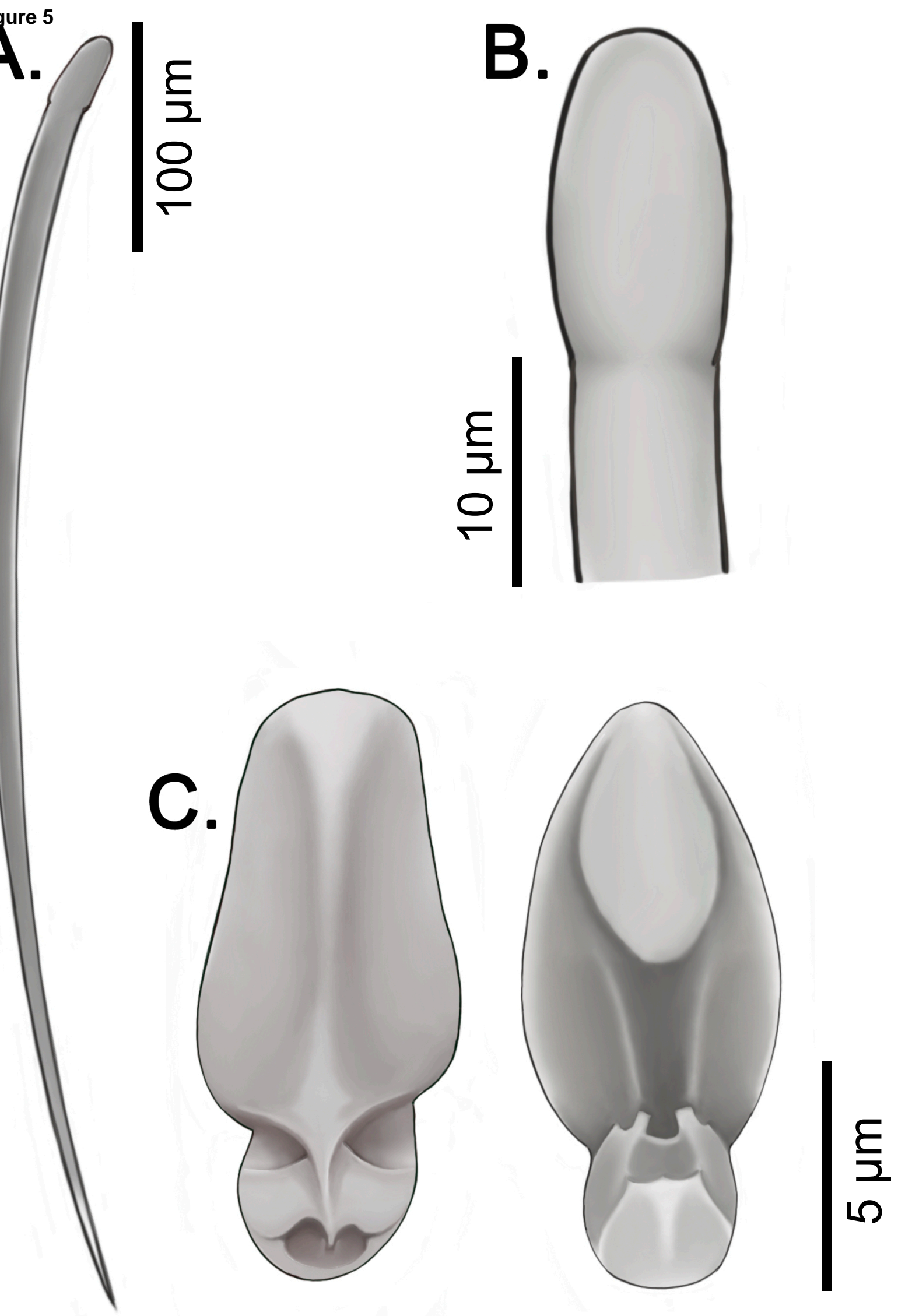
Figure 6

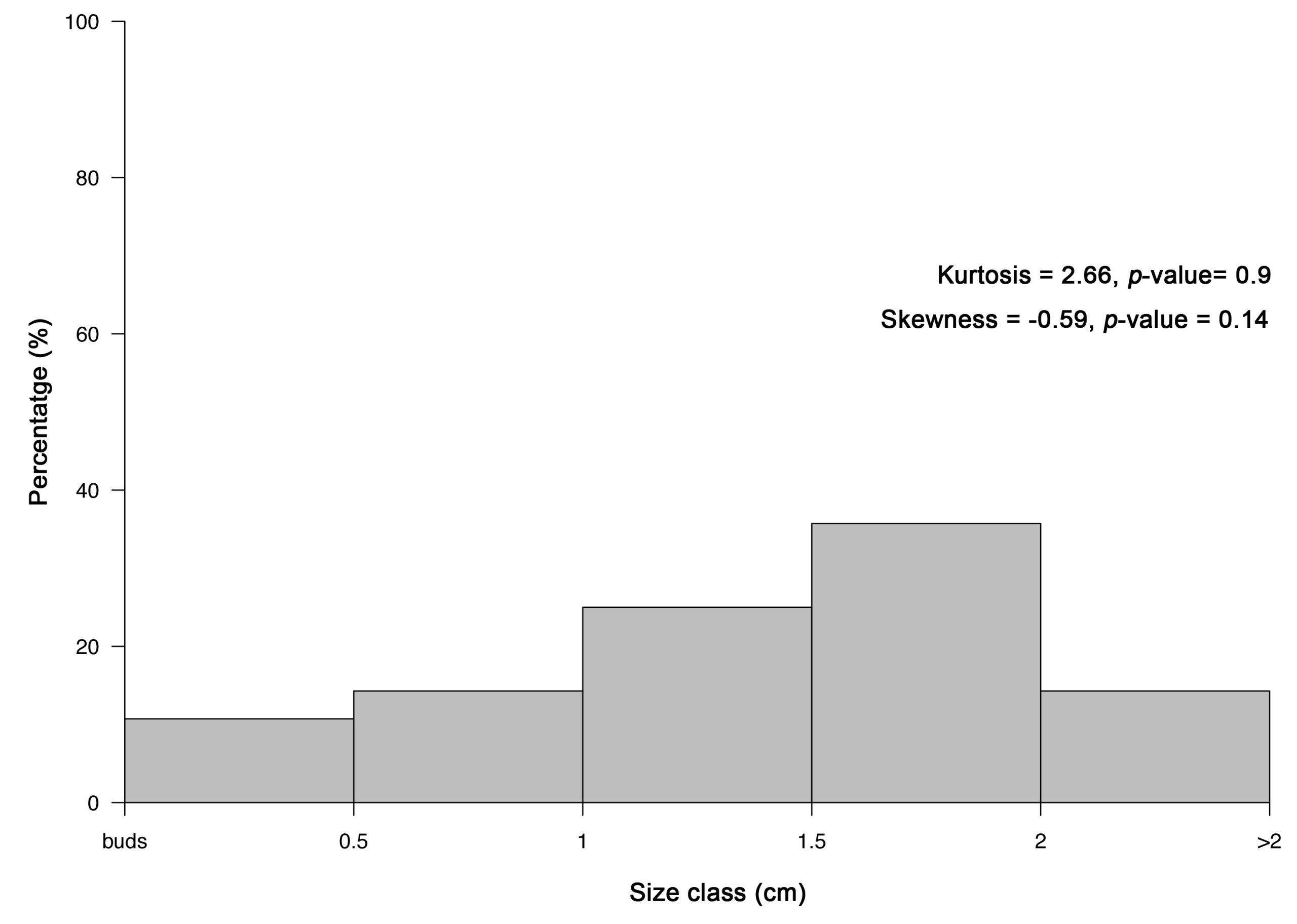

Size class $(\mathrm{cm})$

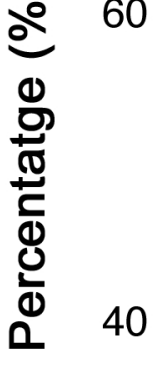


Andreu Santín: Conceptualization, Formal analysis, Writing - Original Draft, Writing - Review \& Editing, Visualization Jordi Grinyó: Resources, Writing Original Draft; Writing - Review \& Editing, Supervision Meri Bilan Resources, Writing - Review \& Editing Stefano Ambroso Resources, Writing - Review \& Editing, Visualization Pere Puig: Resources, Writing - Review \& Editing, Supervision, Project administration, Funding acquisition. 


\section{Declaration of interests}

$\square$ The authors declare that they have no known competing financial interests or personal relationships that could have appeared to influence the work reported in this paper. 